\title{
Health and Social Intervention Programs Among Internally Displaced Population in Eldoret, Western Kenya - Review
}

M. Mulera (Michaela Mulera)1,2, G. Mikolasova (Gertruda Mikolasova)' , V. Krcmery (Vladimir Krcmery)'1, J. Polonova (Jaroslava Polonova)’1, M. Belovicova (Maria Belovicova)', A. Gallova (Andrea Gallova)1, P. Laca (Peter Laca)1, T. Bak (Tadeusz Bak)1, P. Bryndzak (Pavel Bryndzak)', J. Adamcova (Jana Adamcova)', D. Kimuli (Daria Kimuli)1,3, 5. Spanik (Stanislav Spanik)', N. Bujdova (Natasa Bujdova)', M. Jankechova (Monika Jankechova)', C. Mulama (Catherine Mulama)2,3

Original Article

${ }^{1}$ St. Elisabeth University of Health and Social Sciences, PhD programe Bratislava, Slovakia

2 St. Ladislav Batthyany-Strattmann Clinic, Eldoret, Kenya

${ }^{3}$ RSt. Raphael and Bakhita Clinic, Mihango, Kenya

\section{E-mail address:}

mima.mulera@gmail.com

\section{Reprint address:}

Michaela Mulera

St. Ladislav Strattman Clinic

Eldoret, Kenya

Suource: Clinical Social Work and Health Intervention Volume: 8

Issue: 2 Pages: $13-15$

Cited references: 7

\section{Reviewers:}

Victor Namulanda Wanjala

Catholic university of Eastern Africa, Nairobi, Kenya

Daniel J. West, Jr.

University of Scranton, Department of Health Administration and Human Resources, USA

\section{Key words:}

Social interventions, Social work, Health interventions.

\section{Publisher:}

International Society of Applied Preventive Medicine i-gap

CSWHI 2017; 8(2): 13 - 15; DOI 10.22359/cswhi_8_2_02 @ 2017 Clinical Social Work and Health Intervention 


\section{Abstract:}

Around 300,000 people in Kenya were forced to flee their homes after the presidential elections in 2007; another 300,000 were displaced by natural catastrophes, such as droughts and floods. These displaced people usually have very difficult access to healthcare and opportunities for any education. The aim of this short paper is to describe health and social interventions in the Eldoret Area of Kenya where a population of around 120,000 IDP lives.

\section{Conflict of interests:}

The authors whose names are listed in the title of the article certify that they have NO affiliations with or involvement in any organization or entity with any financial interest (such as honoraria; educational grants; participation in speakers' bureaus; membership, employment, consultancies, or other equity interest), or non-financial interest (such as personal or professional relationships, affiliations, knowledge or beliefs) in the subject matter or materials discussed in this manuscript.

\section{Introduction}

This is no comprehensive national data on displacement available for Kenya as it is a problem for the whole geo-region including Nigeria, Somalia and South Sudan. These countries also have the highest numbers of internally displacement peoples. Kenya has no official centralized collection system for data on displacement and the government has never made an attempt to estimate numbers or locations of IDP in that country. However, it is estimated that around 300,000 people were forced to flee their homes after presidential elections following violence in 2007; another 300,000 were displaced by natural catastrophes, such as droughts and floods (1). It is even more difficult to estimate which health and social interventions among IDP populations are being done and how efficient they are. In the Eldoret Area, where St. Elisabeth University has long lasting health and social activities, 120, 000 people were estimated to being displaced after presidential elections (2). Little is known about current numbers of IDPs in that area. The aim of this paper is to describe healthcare and social interventions in the Eldoret Area from 2007 to the present.

\section{Methods}

The St. Ladislav Strattman Clinic in Eldoret serves about 87,000 patients; around 70 on a daily basis. The spectrum of diagnoses varies according to the season and the age of the patients. Most common are respiratory infections, malaria, UTI and diarrhea. The spectrum of laboratory tests available for patients is varied and contributes to the diagnostics.

\section{Results}

Social and educational interventions are carried out at the St. Bakhita House of Hope, which serves 34 girls aged 15-18. They receive two years of professional training as hairdressers, beauticians, tailors, chefs/waiters; taught to work with computers for more receptive integration into the labor market. The girls are from socially disadvantaged environment, either orphans or homeless, many of them are from displaced families. 
Literacy among them is usually poor due to a lack of finances for education. Literacy, however, is not a condition for admission to the program. Another significant educational project serves mother and women who are not educated and therefore finding job is very difficult for them. This project plays a key role in empowering women; most of them are mothers with small children who are also taken care during their mother's education. In total, 124 mothers completed their education and are fully capable to care for the living of their families.

\section{Conclusion}

Eldoret Area is a poor region with many factors influencing the general well-being of the population. High risk of malaria, displacement, droughts and floods and many others dangers contribute to poor education and poor quality of life. Health and social interventions are very efficient tools for empowering vulnerable populations: children, women, orphans and others.

\section{References}

1. IDMC (2016). Africa Report on Internal Displacement. available at: http://www.internal-displacement.org/publications/2016/ africa-report-2016.

2. IOM (2009). Internally Displaced Kenyans Arrive at Camp in Eldoret. Available at: https://www.iom.int/news/internally-displaced-kenyans-arrive-camp-eldoret.
3. KIMULI D, MIKLOSKOVA M, SPANIK S, SUVADA J, CZARNECKI P (2016). Social Pathology II. Warszaw, Management University, 2016. pp.: 455.

4. BUJDOVA N (2015). Development and legal regulation of voluntary actvities in Slovakia. Aspects of cross-border cooperation in the field of volunteering. Liraprint Ukrajina, 2015, 194 s. ISBN 978-617-596-219-0.

5. BUJDOVA N (2015). The elimination of problematic behavior of childen in relation to the State Family Policy. SPAY, Social Pathology Among Youth. St. Elitabeth University of Health and Social Work Bratislava. 2015 s. 93. ISBN 978-80-8132-131-3.

6. POLONOVA J (2015). Respiratory infections after camping in free nature are the current diseases in Migrants to Austria and Germany via Hungary in September 2015: Experience from Roszke and Vamoszabadi. In Krcmery V, Liskova A, Mrazova M, Herdics G, Khali I, Polonova J, Suvada J, Bucko L, Bibza M, Ondova P, Hajj P, Fer I. Clinical Social Work, 2015; 5(2 2015) 33-35. ISSN:2222-386X.

7. POLONOVA J (2015). Self-acceptance, self-esteem building and experiencing of healthy sexuality among youth as the prevention of an abuse in partnerships In Suvada, J. - Tomanek, P. (eds.), 2015. Social pathology among youth (abstract book). Bratislava: St. Elisabeth University of Health and Social Work Bratislava, 2015. ISBN 978-80-8132-131-3. 73 - 74 p. 